\title{
Firma Kârlılı̆̆ını Etkileyen İcsel Faktörler: BİST Gıda, İçecek Endeksinde Yer Alan Firmalar Üzerine Bir Araştırma
}

\author{
Internal Factors Affecting Profitability of Companies: A Research on BiST Food, \\ Beverage Index Companies
}

\begin{abstract}
Eda DIZGIL *
$\ddot{O} Z$

Bu çalışmanın amacı firma kârllllı̆̆na etki eden içsel faktörlerin tespit edilmesidir. Bu amaçla BíST Gıda ve İ̧̧ecek endeksinde hisseleri işlem gören 21 firmanın 2009-2017 finansal tablo verileri kullanilarak panel veri analizi yapllmıştır. Çalışmada kârlllık göstergesi olan değişkenler bağıml değişken olarak kullanılırken kârlllık üzerinde etkisi olduğu düşünülen içsel faktörler yani firmaların finansal yapı, likidite ve faaliyet etkinliği oranları ise bağımsız değişken olarak kullanılmıştır. Çalışmada kârlılı̆̆a etki eden faktörleri tespit etmek amacıyla iki ayrı model kullanılmuştır. Modell'de ekonomik kârlllık oranı, model2'de ise aktif kârlılık oranı bağımlı değişken olarak kullanılmıştır. Modellerde kârlılı̆̆a etki eden faktörleri tespit etmek amactyla on beş farklı finansal oran kullanılmıştır. Yapılan analiz sonucunda modell'de ve model2'de öz sermaye kârllllğ̆, Net işletme sermayesi, kısa vadeli borç oranı, uzun vadeli borç oranı ve alacakların ortalama tahsil süresi değişsenlerinin ekonomik kârlılık oranı ve aktif kârlllık oranı üzerinde anlamlı bir etkisinin olduğu tespit edilmişstir. Her iki modelde de kârlılık değişkenleri üzerinde öz sermaye kârlılı̆̆ı oranının pozitif bir etkisinin olduğu tespit edilirken alacakların ortalama tahsil süresi, kısa vadeli borç oranı, uzun vadeli borç oranı ve net işletme sermayesi değişkenlerinin ise negatif etkisinin olduğu görülmüştür.
\end{abstract}

\section{ANAHTAR KELIMELER}

Panel Veri Analizi, Kârlılık, Aktif kârlılı̆̆̆, Öz kaynak kârlılı̆̆l, Ekonomik Kârlılık.

\begin{abstract}
The aim of this study is to determine the internal factors affecting the profitability of the company. For this purpose, panel data analysis were performed by using the financial data of 2009-2017 of 21 companies whose shares are traded in BIST Food and Beverage index. While the variables with profitability indicators are used as dependent variables, the internal factors that are thought to have an impact on profitability, that is, the financial structure, liquidity and activity efficiency ratios of firms are used as independent variables. Two different models were used to determine the factors that affect profitability. The economic profitability ratio was used in Modell and the asset profitability ratio was used as a dependent variable in model2. Fifteen different financial ratios were used to determine the factors affecting profitability in the models. As a result of the analysis, it has been determined that there is a significant effect on the economic profitability ratio and asset profitability ratio of the variables of equity, profitability, short-term debt ratio, long-term debt ratio and average collection period. In both models, while the rate of return on equity has a positive effect on profitability variables, it was observed that the average collection period, short-term debt ratio, long-term debt ratio and net working capital variables have negative effects.
\end{abstract}

KEYWORDS

Panel Data Analysis, Profitability, Asset profitability, Equity profitability, Economic profitability.

\begin{tabular}{|c|c|c|}
\hline \multicolumn{2}{|c|}{ Makale Geliş Tarihi / Submission Date } & \multicolumn{1}{c|}{$\begin{array}{c}\text { Makale Kabul Tarihi / Date of Acceptance } \\
\text { O2.09.2019 }\end{array}$} \\
\hline \multirow{3}{*}{ Atıf } & $\begin{array}{l}\text { Dizgil, E. (2019). Firma Kârlıllı̆ı̆nı Etkileyen İçsel Faktörler: BİST Gıda, İçecek Endeksinde Yer Alan Firmalar } \\
\text { Üzerine Bir Araştırma. Selçuk Üniversitesi Sosyal Bilimler Meslek Yüksekokulu Dergisi, 22 (2), 420-432. }\end{array}$ \\
\hline
\end{tabular}




\section{Gíriș}

Günümüz finans literatüründe işletmelerin esas amacı firma değerini maksimize etmektir. Burada ana gaye işletmeye yatırım yapan sermayedar ve hissedarlar kazançlarının en üst düzeye çıkarılmasıdır. İşletmelerin bu amaca ulaşmasındaki en önemli faktör ise kâr elde edilmesi, bu kârın sürdürülebilirliğinin sağlaması ve hedeflenen kâra ulaşmada katlanılacak risklerin etkin bir biçimde yönetilmesidir (Karadeniz ve İskenderoğlu, 2011; Korkmaz ve Karaca, 2014: 21).

Finansal yönetimin temel amacı kârlılı̆g maksimum seviyeye çıkarak işletme sahiplerinin refahını artırmaktır. Kârlılık hem yatırım kararları hem finansman kararları hem de performans ölçümünde firmalar için son derece önemli bir kavramdır. Firmaların yatırım yapmadan önce yatırımın borçla mı yoksa öz kaynakla $\mathrm{m}$ finanse edileceğine karar vermeleri gerekir. Eğer öz kaynak finansmanını kullanmayı tercih etmezlerse borçla finansmana yönelecekler ve borçla finansmanın vergi tasarrufu etkisinden yararlanacaklardır. Öz kaynak finansmanını tercih ederlerse borçla finansmanın sağladığı vergi tasarrufu etkisinden faydalanamayacaklardır. Firmalar kâr elde ettiklerinde bu kârı dağıtabilir ya da kârı dağıtmayarak oto finansman olarak kullanabilir. Oto finansman kaynağı ile yatırım projelerini finanse edebilirler. Kârlılık içsel finansmanı doğrudan etkileyen bir unsur olduğu için hem hissedarlar hem de yatırımcılar için son derece önemli bir göstergedir (Korkmaz ve Karaca, 2014: 21). Finansal performans firmaların mali durumları hakkında bilgi veren önemli bir göstergedir. Finansal performansın doğru ve etkili bir şekilde yönetilmesi, firmaların hem kârlılık hem piyasa değerini olumlu yönde etkiler. Bir firmaya ilişkin performans değerlendirmesi yapılırken ilk dikkat edilecek husus firmanın bilanço ve gelir tablosundan elde edilen mali sonuçlardır. Performans değerlemesi ile firmaların ürettikleri mal ve hizmetler, kullandıkları kaynaklar ve elde ettikleri sonuçlar hakkında detaylı bilgiler elde edilir. $\mathrm{Bu}$ açıdan etkin bir performans değerleme sisteminin tasarlanması firmalar için oldukça önemli bir konudur. Performans değerleme sisteminin etkinliği faaliyet ve amaçların doğru olarak tespit edilmesi, uygun bir performans değerleme ölçütünün belirlenmesi, veri toplama, analiz ve sonuçların takip edilmesi ile sağlanır (Aksoy, 2011: 22-23; Doğan ve Topal, 2016: 56).

Finansal performans ölçümünde temel mali tablo verileri ile performans göstergeleri arasındaki ilişkiler farklı açılardan değişik sorular sorularak incelenmektedir. Finansal performans göstergesi olarak kârlılık, satış hacmi, sermaye yapısı kararları, firmanın yaşı ve piyasa durumu ve rekabet gücü gibi birçok faktör çeşitli finansal oranlar aracılığı ile incelenmektedir. Yatırımcıların yatırım kararı verirken dikkate aldığı önemli faktörler ise firmaların kârlılık oranlarıdır. Aktif kârlılık oranı firmaların varlıklarını kâr elde etmede ne kadar etkin ve verimli kullandığını gösterirken öz kaynak kârlılığı oranı ise firmanın kâr elde etmede öz sermayesini ne derece etkin kullandığını göstermektedir. Öz sermayenin getirisi vergi öncesi kârdır. Vergi öncesi kâr ile yabanı kaynak kullanımının ortaya çıkardığı finansman giderinin aktif toplamına bölünmesi ile de firmanın yabancı kaynakları etkin kullanım düzeyi ölçülmektedir (Kocaman ve diğ., 2016: 321). Bu tarz oranların kullanımı ile yapılan karşılaştırmalar daha çok aynı sektörde faaliyette bulunan firmalar açısından anlamlıdır. Çünkü her sektörün kendine has farklılıkları bulunmaktadır (Aydın, 2009: 77).

$\mathrm{Bu}$ çalışmada hisseleri Borsa İstanbul Gıda ve İçecek Endeksinde işlem gören firmaların kârlılığına etki eden içsel yani firma düzeyli faktörlerin tespit edilmesi amaçlanmıştır. Bu amaçla BİST Gıda ve İçecek endeksinde yer alan firmaların 2009-2017 yıllarına ait bilanço ve gelir tablosu verileri kullanılarak önce çalışmanın bağımlı ve bağımsız değişkenlerini oluşturan finansal oranlar hesaplanmış daha sonra bu oranlar arasındaki ilişkileri tespit etmek amacıyla panel veri analizi yöntemi uygulanmıştır.

Makale beş bölümden oluşmaktadır. Giriş bölümünden sonra ikinci bölümde konu ile ilgili literatürde yapılan çalışmalara yer verilmiştir. Üçüncü bölümde makalenin amacı, kapsamı, yöntemi bulunmaktadır. Dördüncü bölümde uygulama ve ampirik bulgulara ilişkin açılamalar yer almaktadır. Beşinci bölümde ise sonuç ve önerilere yer verilerek makale tamamlanmıştır.

\section{LITERATÜR İNCELEMESI}

Literatürde konu ile ilgili yapılmış çalışmalar incelendiğinde firma kârlılığına etki eden faktörlerin genellikle makro ve mikro düzeyli faktörler ya da içsel ve dışsal faktörler olarak gruplandığı görülmektedir. Makro düzeyli faktörler genellikle firmaların kontrol edemediği dışsal faktörlerdir. Bunlar döviz kuru, GSYİH, sanayi üretim endeksi enflasyon vs. değişkenler olarak ifade edilmektedir. İcsel, mikro ya da işletme düzeyli faktörler ise firmanın kontrol edebildiği değişkenler olarak tanımlanmaktadır. Ayrıca çalışmalarda kârlılığa etki eden faktörlerin sektörden sektöre, ülkeden ülkeye farkl1lık gösterdiği de görülmüştür. Bu bölümde firma kârlılığına etki eden faktörlerin tespitine yönelik olarak yurt içi ve yurt dışında yapılmış çalışmaların kısa özetlerine yer verilmiştir.

Haniffa ve Hudaib (2006) çalışmalarında 1996-2000 yılları arasında Malezya'da faaliyet gösteren firmaların kârlılığına etki eden faktörleri araştırdıkları çalışmada finansal yapı kaldıraç oranı ile kârlılık 
arasındaki ilişkiyi araştırmışlardır. Çalışma sonucunda kaldıraç oranının firma kârlılı̆̆ üzerinde negatif etkisi olduğunu tespit etmişlerdir. Kaldıraç oranındaki artışın firma kârlılığını azalttığını ifade etmişlerdir.

Albayrak ve Akbulut (2008), İMKB Sanayi ve hizmet sektörlerinde işlem gören firmaların kârlılık düzeyine etki eden faktörleri araştırdıkları çalışmalarında İMKB'de sanayi ve hizmet sektöründeki firmalardan orantılı tabakalı örnekleme yöntemiyle seçilen 55 firmaya ait 2004-2006 yıllarına ait verileri kullandıkları çalışmalarında analiz için en küçük kareler tekniği (Prais-Winsten) yöntemini tercih etmişler. Çalışmada kullanılan bağımlı ve bağımsız değişkenler ise sırasıyla kârlılıkla ilgili bağımlı değişkenler net kâr/ toplam aktifler, faiz ve vergi öncesi kâr/ toplam aktifler, net kâr/ öz sermaye, vergi öncesi kâr/ öz sermaye, net kâr/ net satışlar, brüt kâr/ net satışlara oranı, net faaliyet kârı/ net satışlar ve net kâr/ hisse senedi sayısıdır. Kârlılık yapılarını açıklamada kullanılan bağımsız değişkenler finansal yapı kaldıraç değişkenleri, likidite oranı değişkenleri, varlık kullanım etkinliği değişkenleri, piyasa değeri ve işletme büyüklüğü değişkenlerinden oluşmaktadır. Yapılan analiz sonucunda işletmelerin kârlılık seviyelerinin yükseltilmesi için toplam kaynaklar içinde yabancı kaynakları ve likidite oranlarını (faaliyet kâr marjı için) göreceli olarak azaltmaları; işletme büyüklüklerini, stok devir hızlarını ve piyasa değerlerini arttırmaları gerektiği ifade edilmiştir.

Aktan ve Bodur (2011) çalışmalarında KOBİ niteliğinde küçük işletmelerin bilanço ve gelir tablolarını kullanarak finansal rasyoları vasıtasıyla finansal analizlerin yapabileceğini ve bankaların kredi değerlendirmede hangi finansal oranları dikkate aldığını araştırmışlardır. Bu doğrultuda hangi finansal oranın ne işe yaradığını ve nasıl hesaplandığını detaylı olarak ele almışlar ve finansal oranların işletmeler ve işletme çevresi açısından son derece önemli olduğunu vurgulamışlardır.

Chen (2012) Norveç, İsveç, Danimarka ve Finlandiya ülkelerinde faaliyette bulunan en büyük 20 şirketin 2008-2010 y1lına ait verilerini kullanarak firma performansına etki eden faktörlerin tespit edilmesine yönelik bir araştırma yapmıştır. Çalışma sonucunda firma yaşı ile kârlılık göstergeleri arasında anlamlı bir ilişki bulamazken kaldıraç oranı ile kârlılık değişkenleri arasında negatif yönlü anlamlı bir ilişki tespit etmiştir.

Almajali ve Alamro (2012) hisseleri Ürdün borsasında işlem gören 25 sigorta firmasının finansal performansına etki eden faktörleri araştırdıkları çalışmalarında 2002-2007 yıllarına ait veri setini kullanarak çoklu doğrusal regresyon analizi yapmışlardır. Analizde likidite oranı, kaldıraç oranı, büyüklük gibi değişkenlerin firma kârlılığı üzerine etkisi araştırmışlardır. Analiz sonucunda bu değişkenlerin firma kârlılığ1 üzerinde pozitif yönlü etkisi olduğunu tespit etmişlerdir.

Ujunwa (2012) kârlılık üzerine etki eden faktörleri araştırdığı çalışmada Nijerya'da faaliyet gösteren firmaların 1991-2008 yıllarına ait verileri kullanılarak çoklu doğrusal regresyon analizi yapmıştır. Analiz sonucunda toplam varlıklar ile kârlılık arasında negatif yönlü anlamlı bir ilişki tespit etmiş̧ir.

Korkmaz ve Karaca (2014) üretim işletmelerinde kârlılığın finansal belirleyicilerinin tespit edilmesine yönelik yaptıkları çalışmada BİST İmalat Sanayiinde yer alan 78 firmanın 2000-2011 yıllarına ait verilerini ve panel regresyon analiz yöntemini kullanmışlardır. Çalışamada üç ayrı modelle verilerin analizini gerçekleştirmişlerdir. İlk modelde hisse başına kazanç, ikinci modelde net kâr/öz sermaye ve üçüncü modelde ise net kâr/ toplam aktif oranı bağımlı değişken olarak kullanmışlardır. Çalışmada kullanılan bağımsız değişkenler ise Net Satış / Toplam Aktif, Satılan Mamul Maliyet / Stoklar, Net Satışlar / Ticari Alacaklar, Cari Oran, Duran Varlık / Toplam Aktif, Maddi Duran Varlık / Uzun Vadeli Yabancı Kaynak, Net Satışlar / Dönen Varlıklar ve Toplam Borç / Toplam Aktif gibi finansal oranlardır. Yapılan analiz sonucunda üç modelde de toplam borç/ toplam aktif, duran varlık/ toplam aktif ve maddi duran varlık ve uzun vadeli yabancı kaynak değişkenleri ile modellerde kullanılan bağımlı değişkenler arasında anlamlı ilişkiler tespit edilmiştir.

Doğan ve Topal (2016) kârlılığı belirleyen finansal faktörlerin araştırıldığı çalışmada yazarlar imalat sanayiinde faaliyet gösteren 136 firmanın 2005-2016 yılları arasındaki verileri kullanılarak panel veri analiz yöntemini uygulamışlardır. Analizde bağımlı değişken olarak varlık kârlılığı ve öz sermaye kârlılığı oranı kullanılırken firma büyüklüğü, kaldıraç oranı, cari oran ve firmanın yaşı ise bağımsız değişken olarak kullanılmıştır. Analiz sonucunda Varlık Kârlılığı ve Öz sermaye Kârlılığı ile toplam varlıklar arasında pozitif yönlü bir ilişki tespit edilirken kaldıraç oranı ile kârlılık oranları arasında ise negatif bir ilişki olduğu ifade edilmiştir. Cari oran ve firma yaşı ile kârlılık oranları arasında ise herhangi bir ilişki bulunmamıştır.

Kocaman ve diğ. (2016) ekonomik kârlılığa etki eden faktörleri araştırdıkları çalışmada yazarlar İstanbul Sanayi Odasının her yıl açıkladığ 500 büyük sanayi kuruluşu içerisinden 17 yıl boyunca ilk 100'de yer almış ve hisseleri Borsa İstanbul'da işlem gören 15 firmanın 1997-2013 yıllarına ait verileri kullanılarak panel veri analizi yapmışlardır. Çalışmada ekonomik kârlılık oranı bağımlı değişken olarak kullanılmıştır. Bağımsız değişkenler ise net kâr marjı, alacak devir hızı, cari oran, duran varlık/ aktif toplamı, kaldıraç oranı, net işletme sermayesi/ net satış oranı ve net işletme sermayesi devir hızı olarak belirlenmiştir. Yapılan analiz sonucunda ekonomik kârlılık oranı ile Net Kâr Marjı, Alacak Devir Hızı, Kaldıraç Oranı ve Duran Varlıkların Aktif Toplamına Oranı arasında anlamlı bir ilişki olduğunu ifade etmişlerdir. Buna karşın Ekonomik Kârılılık ile Cari 
Oran, Net İşletme Sermayesi/Net Satışlar ve Net İşletme Sermayesi Devir Hızı (Bağımsız Değişkenler) arasında herhangi bir ilişki olmadığı ifade edilmiştir.

Coşkun ve Topaloğlu (2016) Borsa İstanbul'daki firmaların finansal performansına etki eden makroekonomik faktörlerin araştırıldığı çalışmada yazarlar BİST100 endeksinde 2010-2015 yılları arasında faaliyet gösteren 37 firmanın verilerini kullanarak panel veri analizi yapmışlardır. Analizde bağımlı değişken olarak aktif kârlılığı, öz kaynak kârlılığı ve satış kârlılı̆̆ değişkenlerini kullanmışlardır. Bağımsız değişkenler ise ticari kredilere uygulanan faiz oranı, reel efektif döviz kuru, enflasyon oranı ve kamu altyapı harcamaları / GSYIH oranı ile temsil edilmiştir. Yapılan analiz sonucunda makroekonomik faktörlerle performans değişkenleri arasında çeşitli yönlerde istatistiki olarak anlamlı ilişkiler tespit edilmiştir.

\section{2.ÇALIŞMANIN AMACI KAPSAMI VE YÖNTEMI}

\section{1.Çalışmanın Amacı ve Kapsamı}

Bu çalı̧̧manın amacı hisseleri Borsa İstanbul Gıda ve İçecek Endeksinde işlem gören 21 firmanın kârlılığına etki eden içsel faktörlerin tespit edilmesidir. Burada içsel faktörler olarak ifade edilen işletme düzeyli yani işletmenin kontrol edebildiği faktörlerdir. Firma kârlılığı, firma yöneticileri yatırımcılar ve tüm paydaşlar için oldukça önemli bir konudur. Bu amaçla endekste faaliyet gösteren firmaların 2009-2017 yıllarına ait yıllık bilanço ve gelir tablosu verileri kullanılarak panel veri analizi yapılmıştır. Veriler kamuyu aydınlatma platformunun internet sitesinden alınmıştır. Bu çalışmada diğer çalışmalardan farklı olarak endeks bazlı bir araştırma yapılmış ve bu doğrultuda ise Gıda ve İçecek Endeksi seçilmiştir. Bu endeksin seçilme nedeni ise endekste faaliyet gösteren firmaların likiditelerinin yüksek ve nakit yönetimlerinin ise etkin olduğunun düşünülmesidir. Çünkü literatürde likidite ve nakit yönetimindeki etkinliğinde kârlılık üzerinde olumlu etkilerinin olduğu ifade edilmektedir. Ayrıca bu hususun değerlendirilmesi amaciyla da bu endeks seçilmiştir. Örneklemde 21 firma bulunmasına rağmen 5 firmanın verilerinde eksiklik olduğu için firma sayıs1 16 olarak belirlenmiştir. Endekste yer alan firmaları tablo:1 de gösterilmiştir. Tabloda * işareti ile gösterilen firmaların verilerine ulaşılamadığından bu firmalar çalışmaya dâhil edilmemişılerdir.

Tablo 1: Bist Gıda ve İçecek Endeksinde Yer Alan Firmalar

\begin{tabular}{|c|c|c|}
\hline & BİST Kodu & Şirketler \\
\hline 1 & AEFES & Anadolu Efes Biracılık Malt Sanayi A.Ş \\
\hline 2 & AVOD & A.V.O.D Kurutulmuş Gıda ve Tarım Ürünleri A.Ş* \\
\hline 3 & BANVT & Banvit Vitaminli Yem Sanayi A.Ş \\
\hline 4 & CCOLA & Coca Cola İçecek A.Ş \\
\hline 5 & ERSU & ERSU Meyve ve Gıda Sanayi A.Ş* \\
\hline 6 & KENT & Kent Gıda Maddeler Sanayi ve Ticaret A.Ş \\
\hline 7 & KERVT & Kerevitaş Gıda Sanayi ve Ticaret A.Ş \\
\hline 8 & KNFRT & Konfort Gıda Sanayi ve Ticaret A.Ş \\
\hline 9 & KRSTL & Kristal Kola ve Meşrubat Sanayi ve Ticaret A.Ş \\
\hline 10 & MERKO & Merko Gıda Sanayi ve Ticaret A.Ş \\
\hline 11 & OYLUM & Oylum Sinai Yatırımlar A.Ş* \\
\hline 12 & PENGD & Penguen Gıda Sanayi ve Ticaret A.Ş \\
\hline 13 & PETUN & Pınar Entegre Et ve Un Sanayi A.Ş \\
\hline 14 & PINSU & Pınar Su Sanayi ve Ticaret A.Ș \\
\hline
\end{tabular}




\begin{tabular}{|l|l|l|}
\hline $\mathbf{1 5}$ & PNSÜT & Pınar Süt Mamulleri Sanayi ve Ticaret A.Ş \\
\hline $\mathbf{1 6}$ & TATGD & Tat Gıda Sanayi A.Ş \\
\hline $\mathbf{1 7}$ & TUKAS & Tukaş Gıda Sanayi ve Ticaret A.Ş \\
\hline $\mathbf{1 8}$ & TBORG & Türk TUBORG Bira ve Malt Sanayi A.Ş \\
\hline $\mathbf{1 9}$ & ULUUN & ULUSOY Un Sanayi ve Ticaret A.Ş* \\
\hline $\mathbf{2 0}$ & ULKER & Ülker Bisküvi Sanayi A.Ş \\
\hline $\mathbf{2 1}$ & VANGD & Vanet Gıda Sanayi ve Dış Ticaret A.Ş* \\
\hline
\end{tabular}

Kaynak: Kamuyu Aydınlatma Platformu (KAP)

\section{2.Çalışmanın Yöntemi}

Çalışmada öncelikle firmaların yıllık bilanço ve gelir tablolarından elde edilen veriler kullanılarak excel paket programı yardımıyla analizde kullanılacak finansal oranlar hesaplanmıştır. Daha sonra ise panel veri analizi yapılmıştır. Panel veri analizi hem yatay hem de dikey kesit verilerini analiz etmede kullanılan bir çeşit çoklu regresyon analizi yöntemidir. Panel veri analizi kesitsel verilerin zaman serileri ile eş zamanlı olarak tek formda analiz edilmesi esasına dayanır $\mathrm{Bu}$ analiz sayesinde birden fazla birim ve her birime ait zaman boyutu analizden rahatlıkla görülebilmektedir. Panel veri yöntemi kesitsel ve zaman serisi verilerini birlikte değerlendiren bir metot olarak kullanılmaktadır. Zaman serisinin eşit uzunlukta olup olmamasına göre iki türü vardır. Her birimin zaman serisi eşit uzunlukta ise, dengeli panel veri, zaman serilerinin uzunlukları birbirinden farklı ise dengesiz panel veri olarak adlandırılmaktadır. Ayrıca statik panel veri ve dinamik panel veri modelleri olmak üzere ikiye ayrılmaktadır. Statik panel veri modellerinde bağımlı değişkeni açıklamak için hem bağımlı hem de bağımsız değişkenin gecikmeli değerleri modele eklenmez. Dinamik panel veri modellerinde ise diğer modelden farklı olarak gecikmeli değişken ya da değişkenler modele eklenebilir (Yerdelen Tatoğlu, 2012: 65; Coşkun ve Topaloğlu, 2016: 6). Panel veri analizinde ise Eviews 9 paket programı kullanılmıştır. Çalışmada kârlılık üzerinde etkili olan içsel faktörleri tespit etmek amacıyla 2 farklı bağımlı değişken kullanılarak 2 ayrı model oluşturulmuştur. Analizde kullanılan bağımlı ve bağımsız değişkenler ise tablo: 2 de listelenmiştir.

Tablo 2: Bağımlı ve Bağımsız Değişkenler

\begin{tabular}{|c|c|c|}
\hline Değişkenler & Açıklama & Kisa Ad 1 \\
\hline \multicolumn{3}{|l|}{ Bağımlı değişkenler } \\
\hline Aktif Kârlıık Oranı & Net Kâr/ Toplam Aktif & $\mathrm{AK}$ \\
\hline Ekonomik Kârlılık Oranı & Faiz ve vergi öncesi kâr/ Toplam Aktif & EK \\
\hline \multicolumn{3}{|l|}{ Bağımsız değişkenler } \\
\hline Kısa vadeli borç oranı & K1sa vadeli borç/ Toplam Aktif & KVBO \\
\hline Uzun vadeli borç oranı & Uzun vadeli borç/Toplam Aktif & UVBO \\
\hline Öz kaynak oranı & Öz kaynaklar/ Toplam Aktif & OKTA \\
\hline Öz sermaye Kârlılık Oranı & Net Kâr/ Öz sermaye & OSK \\
\hline Net İşletme Sermayesi & Dönen varlıklar- Kısa vadeli yabancı kaynaklar & Nis \\
\hline Alacakların Ortalama Tahsil Süresi & (Ticari Alacaklar x 365) / Satışlar & AOTS \\
\hline
\end{tabular}




\section{UYGULAMA}

Çalışmada BİST Gıda ve İçecek Endeksinde yer alan verilerine eksiksiz ulaşılabilen 16 firmanın 2009-2017 yıllarına verileri kullanılarak dengeli panel veri analizi yapılmıştır. Panel veri analizi yönteminde, gruplar arası heterojenlik etkilerinin kontrolü sağlanabilir, değişkenler arası çoklu bağlantı problemleri azaltılabilir ve tahmincilerin etkinliği arttırılabilir bu bakımından panel veri analizi yöntemi diğer zaman faktörü analizlerinden farklılık gösterir. Bu çalışmada veri seti hem yatay kesit hem dikey kesit olduğu için bu yöntem uygun bulunmuştur. Veriler Eviews paket programı kullanılarak analiz edilmiştir. Bu doğrultuda analizde iki farklı model kullanılarak firmaların hem aktif kârlılık oranı hem de ekonomik kârlılık oranlarına etki eden faktörler tespit edilmeye çalışılmıştır. Çalışmada kullanılan modeller aşağıda yer almaktadır.

Model 1: $\mathrm{EK}$ it $=\beta 1+\beta 2 \mathrm{OSKit}+\beta 3 \mathrm{NISit}+\beta 4 \mathrm{KVBOit}+\beta 5 \mathrm{UVBO}$ it $+\beta 6 \mathrm{OKTAit}+\beta 7 \mathrm{AOTSit}+\varepsilon$ it Model 2: $A K i t=\beta 1+\beta 2$ AOTSit $+\beta 3 \mathrm{KVBOit}+\beta 4 \mathrm{NISit}+\beta 5 \mathrm{OSKit}+\beta 6 \mathrm{UVBO}$ it $+\varepsilon$ it

Çalışmada kullanılan değişkenlere ilişkin tanımlayıcı istatistikler tablo:3 'de yer almaktadır. Çalışmada 15 farklı finansal oran bağımsız değişken olarak kullanılmışırı. Ancak Asit test oranı ve cari oran ile alacakların ortalama tahsil süresi değişkenleri arasında yüksek korelasyon ilişkisi bulunduğundan dolayı bu değişkenler modellerden çıkarılmıştır.

Tablo 3: Bağımlı ve Bağımsız Değişkenlere İlişkin Tanımlayıcı İstatistikler

\begin{tabular}{|c|c|c|c|c|}
\hline Değişkenler & Maksimum & Minimum & Ortalama & Standart Sapma \\
\hline AK & 0.246 & -0.21 & 0.033 & 0.085 \\
\hline EK & 0.27 & -0.23 & 0.034 & 0.095 \\
\hline KVBO & 0.88 & 0.05 & 0.368 & 0.189 \\
\hline AOTS & 549 & 20 & 84.78 & 2.96 \\
\hline OKAT & 36 & -0.14 & 0.72 & 1.97 \\
\hline OSK & 4.40 & -13.68 & 0.19 & 0.139 \\
\hline UVBO & 0.66 & 0.007 & 0.144 & 2.12 \\
\hline LOGNiS & 21.75 & 10.78 & 16.93 & \\
\hline
\end{tabular}

Tabloda 2009-2017 yıllarında BíST Gıda ve İçecek Endeksinde yer alan 16 firmanın modelde kullanılan bağımlı ve bağımsız değişkenlerine ilişkin tanımlayıcı istatistikleri yer almaktadır. Aktif karlılık oranı ve ekonomik karlılık oranları firmaların ne ölçüde verimli kullandıklarını göstermektedir. Ekonomik karlılık oranı varlık karlılığını faiz ve vergi öncesi kar üzerinden belirlerken aktif karlılık oranı ise dönem net karı üzerinden belirlemektedir. $\mathrm{Bu}$ oranların 1'e yakın çıkması varlıkların verimli ve karlı bir şekilde kullanıldığını göstermektedir. Ancak tabloyu incelediğimizde gıda ve içecek endeksinde karlılık oranlarının düşük olduğu görülmektedir. Firmaların aktif karlılık oranları ve ekonomik karlılık oranları ortalama \%3olarak belirlenmiştir. Kısa vadeli borç oranı toplam aktiflerin ne kadarlık bir kısmının kısa vadeli kaynaklarla finanse edildiğini göstermektedir. İncelenen firmaların ortalama \%36 oranında kısa vadeli yabancı kaynaklarla ile finanse edildiği belirlenmiştir. Uzun vadeli borç oranı da toplam aktiflerin ne kadarlık kısmının uzun vadeli yabancı kaynaklarla finanse edildiğini gösterir. Bu değerde ortalama \%14 olarak belirlenmiştir. Alacakların ortalama tahsil süresi; alacakların satıştan ortalama kaç gün süre sonra tahsil edildiğini gösterir. $\mathrm{Bu}$ oran endekste yer alan firmalar için ortalama 84 gün olarak belirlenmiştir. Öz kaynak oranı toplam aktifler içerindeki öz kaynak oranını göstermektedir. Bu oran ortalama \%72 olarak belirlenmiştir. Bu oranın yüksek olması firmanın uzun vadeli borçlarını ödeyememe riskini düşürür. Öz sermaye karlılık oranı ise öz sermayenin ne ölçüde karlı olarak kullanıldığını göstermektedir. Ortalama \%19 olarak belirlenmiştir. Net İşletme Sermayesi kısa vadeli borçlar ödendikten sonra kalan dönen varlık büyüklüğünü ifade eder.net işletme sermayesinin pozitif olması firmanın günlük faaliyetlerini sorunsuz bir biçimde devam ettirmesi açısından önem arz eder. Standart sapma serilerde değerler arasındaki farklılığın ölçüsüdür. Standart sapması en yüksek 
değişken alacakların ortalama tahsil süredir. Bu seride standart sapmanın yüksek olması serideki değerler arasındaki farkın yüksek olduğunu göstermektedir.

Değişkenlerin birbirleri arasında ilişki olup olmadığını tespit etmek amacıyla korelasyon analizi yapılmıştır. Bu analiz iki ya da daha fazla değişken arasında ilişki olup olmadığını tespit etmek amacıyla yapılmaktadır. Analiz sonucunda değişkenler arası ilişkilerin yönü ve büyüklüğü görülebilmektedir. Korelasyon kat sayıları 0 ila 1 arasında değişiklik gösterir. Pozitif veya negatif değer alabilir. Analize ilişkin sonuçlar ise tablo:4'de yer almaktadır.

Tablo 4: Korelasyon Analizi Sonuçları

\begin{tabular}{|c|c|c|c|c|c|c|c|c|}
\hline & EK & lognis & AOTS & UVBO & OSK & OKTA & KVBO & AK \\
\hline EK & 1.00 & & & & & & & \\
\hline Lognis & -0.07 & 1.00 & & & & & & \\
\hline AOTS & -0.16 & 0.10 & 1.00 & & & & & \\
\hline UVBO & -0.21 & -0.04 & -0.26 & 1.00 & & & & \\
\hline OSK & 0.51 & -0.00 & -0.10 & -0.04 & 1.00 & & & \\
\hline OKTA & 0.11 & 0.07 & -0.01 & 0.008 & 0.04 & 1.00 & & \\
\hline KVBO & -0.39 & 0.11 & -0.12 & -0.00 & -0.48 & -0.05 & 1.00 & \\
\hline AK & 0.90 & -0.06 & -0.18 & -0.17 & 0.53 & 0.10 & -0.41 & 1.00 \\
\hline
\end{tabular}

Tablo 4'de yer alan korelasyon matrisini incelediğimizde ekonomik kârlılık değişkeni ile aktif kârlılık değişkeni arasında yüksek düzeyli pozitif bir korelasyon ilişkisinin bulunduğunu görmekteyiz. Ancak bu iki değişken modellerde aynı anda kullanılmadığ 1 için bu durum oluşturulan modellerin güvenilirliğini etkilememektedir. Bağımsız değişkenler arasında güçlü ilişki olması modelde çoklu doğrusallık sorununu yol açmaktadır. Bu doğrultuda diğer değişkenler arasındaki korelasyon analizi sonuçlarına baktığımızda güçlü bir korelasyon ilişkisi bulunmadığını görmekteyiz. Buna göre modelleri oluşturan değişkenler arasında çoklu doğrusal bağıntı sorunu olmadığını söyleyebiliriz. Bu aşamadan sonra ise modellerde kullanılan birimler ve seriler arasında yatay kesit bağımlılı̆g 1 olup olmadığını tespit etmek amacıyla hem model bazlı hem de değişken bazlı yatay kesit bağımlılık testleri uygulanmıştır.

Eğer seriler arasında yatay kesit bağımlılı̆̆ varsa bu durumda analiz sonuçları gerçeği yansıtmayacak sapmalı ve tutarsız olacaktır. Serilerde yatay kesit bağımlılı̆g olup olmadığını test etmek amaciyla BreuschPagan (1980) LM testi, Pesaran (2004) CD ve CDlm testleri yapılmıştır. Burada yapılan testlerden hangisinin kullanılacağına karar vermek için veri setine bakılmaktadır. Eğer zaman boyutu yatay kesit boyutundan büyük ise Breusch-Pagan (1980) LM testi, yatay kesit ile zaman boyutu arasına çok büyük farkın olmadığı durumda Pesaran (2004) CDlm testi, yatay kesit zaman boyundan büyük ise bu durumda da Pesaran (2004) CD testinin sonuçları dikkate alınmaktadır (Topaloğlu, 2018: 22). Bu çalışmada yatay kesit boyutu zaman boyutundan büyük olduğu için Pesaran (2004) CD testi sonuçları dikkate alınmıştır. Yatay kesit bağımlılık testi paneli oluşturan birimler bazında ve değişken bazında ayrı incelenmiştir. Tablo:5'da modell ve model 2 için paneli oluşturan birimler bazında yatay kesit bağımlılık testi sonuçları yer almaktadır. 
Tablo:5 Model1 ve Model2 İçin Yatay Kesit Bağımlılık Testlerine İlişkin Sonuçlar

\begin{tabular}{|c|c|c|c|c|}
\hline Yatay Kesit Bağımlılı Testleri & \multicolumn{2}{|c|}{ model1 } & \multicolumn{2}{c|}{ model2 } \\
\hline & İstatistik & Olasılık & İstatistik & Olasıllk \\
\hline CDLM (BP,1980) & 134.8147 & 0.1680 & 129.3568 & 0.2638 \\
\hline CDLM(pesaran,2004) & -0.076511 & 0.9390 & -0.428817 & 0.6681 \\
\hline CD(Pesaran,2004) & -1.476526 & 0.1398 & -1.831464 & 0.0670 \\
\hline LMadj & -1.219369 & 0.2227 & -1.571674 & 0.1160 \\
\hline
\end{tabular}

Model bazlı yatay kesit bağımlılık testlerine ilişkin sonuçların yer aldığı tabloyu incelediğimizde her iki modelde de olasılık değerinin 0,05 değerin büyük olduğu görülmüştür. Burada sıfir hipotezi yatay kesit bağımlılığı yoktur. Alternatif hipotez ise yatay kesit bağımlılığı vardır şeklinde ifade edilmektedir. Modellerde olasılık değeri 0,05 den büyük çıktığı için her iki modelde de sıfır hipotezi kabul edilmiştir. Yani modellerde yer alan birimler arasında yatay kesit bağımlılı̆̆ının bulunmadığ değişken bazlı yatay kesit bağımlılığı testi uygulanmıştır. Bu testler ise değişkenlerin durağanlık sınamalarını test ederken hangi birim kök testlerinin kullanılacağına karar vermek için yapılmaktadır.

Tablo:6 Değişken Bazında Yatay Kesit Bağımlıık Testlerine İlişkin Sonuçlar

\begin{tabular}{|c|c|c|c|c|c|c|}
\hline \multirow[t]{2}{*}{ Değişkenler } & \multicolumn{2}{|c|}{ LM(Breusch, Pagan) } & \multicolumn{2}{|l|}{$\begin{array}{l}\text { CDlm } \\
\text { (Pesaran ) }\end{array}$} & \multicolumn{2}{|l|}{$\begin{array}{l}\text { CD } \\
\text { (Pesaran) }\end{array}$} \\
\hline & ist. & Olasıllık & ist. & Olasilık & ist. & Olasilık \\
\hline $\mathrm{AK}$ & 143.5844 & 0.0701 & 0.489574 & 0.6244 & -0.097474 & 0.9223 \\
\hline EK & 187.1576 & 0.0001 & 3.302206 & 0.0010 & 0.127171 & 0.8988 \\
\hline KVBO & 138.9479 & 0.1138 & 0.190284 & 0.8491 & 0.208126 & 0.8351 \\
\hline UVBO & 135.1580 & 0.1629 & -0.054349 & 0.9567 & -1.008006 & 0.3135 \\
\hline OKTA & 292.9675 & 0.0000 & 10.13221 & 0.0000 & -0.235261 & 0.8140 \\
\hline OSK & 175.3340 & 0.0007 & 2.538997 & 0.0111 & 0.751112 & 0.4526 \\
\hline LOGNIS & 229.7652 & 0.0000 & 6.052515 & 0.0000 & -0.269109 & 0.7878 \\
\hline NINS & 193.6932 & 0.0000 & 3.724082 & 0.0002 & -1.215513 & 0.2242 \\
\hline AOTS & 182.9910 & 0.0002 & 3.033255 & 0.0024 & 0.266875 & 0.7896 \\
\hline
\end{tabular}

Yatay kesit testi sonuçlarına baktığımızda bütün değişkenlerin olasılık değerlerinin 0,05 kritik değerinden yüksek olduğu görülmektedir. Bu sonuç değişkenler arasında yatay kesit bağımlılığının bulunmadığını göstermektedir. Yani burada kullanılan değişkenlerde birinci nesil birim kök testleri kullanılması uygundur. $\mathrm{Bu}$ doğrultuda değişkenlerin durağan olup olmadıklarını tespit etmek amaciyla birinci nesil birim kök testlerinden LLC ve ADF testleri yapılmıştır. Bu testlere ilişkin sonuçlar tablo:7 da yer almaktadır. 
Tablo:7 Birim Kök Testlerine İlişkin Sonuçlar

\begin{tabular}{|l|l|l|l|l|l|}
\hline \multirow{2}{*}{ Değişkenler } & \multirow{2}{*}{ Birim Kök Testi } & \multicolumn{2}{|l}{ Düzey değerinde } & \multicolumn{2}{l}{ Birincil fark } \\
\cline { 3 - 6 } & & T istatistik & Olas1lı değeri & T istatistik & Olasıllk değeri \\
\hline AK & LLC & -3.03340 & $0.0012^{*}$ & -11.4550 & $0.0000^{*}$ \\
\hline EK & LLC & -3.49019 & $0.0002^{*}$ & -11.1782 & $0.0000^{*}$ \\
\hline KVBO & LLC & 0.66266 & 0.7462 & -9.92627 & $0.0000^{*}$ \\
\hline UVBO & LLC & -0.29317 & 0.3847 & -9.77966 & $0.0000^{*}$ \\
\hline OKTA & LLC & -8.33125 & $0.0000^{*}$ & -133.417 & $0.0000^{*}$ \\
\hline OSK & LLC & -0.67416 & 0.2501 & -8.80171 & $0.0000^{*}$ \\
\hline LOGNiS & LLC & 2.47537 & 0.9933 & -8.77282 & $0.0000^{*}$ \\
\hline AOTS & LLC & -3.54544 & $0.0002^{*}$ & -10.5521 & $0.0000^{*}$ \\
\hline AK & ADF & 51.1093 & $0.0174 *$ & 123.676 & $0.0000^{*}$ \\
\hline EK & ADF & 46.7720 & $0.0444^{*}$ & 120.289 & $0.0000^{*}$ \\
\hline KVBO & ADF & 21.3288 & 0.9242 & 114.823 & $0.0000^{*}$ \\
\hline UVBO & ADF & 25.5571 & 0.7829 & 91.2716 & $0.0000^{*}$ \\
\hline OKTA & ADF & 63.8306 & $0.0007^{*}$ & 95.3239 & $0.0000^{*}$ \\
\hline OSK & ADF & 31.5669 & 0.4884 & 103.684 & $0.0000^{*}$ \\
\hline NiS & ADF & 11.9395 & 0.9995 & 123.509 & $0.0000^{*}$ \\
\hline AOTS & ADF & 40.4293 & 0.1457 & 114.806 & $0.0000^{*}$ \\
\hline
\end{tabular}

*\%1, \%5,\%10 Anlamlılık düzeyini ifade etmektedir

Tabloda serilerin durağanlık sınamasını yapmak amacıyla Levin, Lin ve Chu(LLC), Genişletilmiş Dickey Fuller( ADF) birim kök testleri uygulanmıştır. Tabloyu incelediğimizde AK, EK, OKTA, AOTS serilerinin LLC testi sonuçlarına göre düzey değerlerinde durağan olduğu tespit edilmiştir. ADF testi sonuçlarına baktığımızda AK, EK ve OKTA serilerinin düzey değerlerinde durağan olduğu görülmüştür. Ancak diğer serilerin düzey değerinde durağan olmadığı sabit terimli- trendli değerlerinde ve birincil farklarında durağan olduğu tespit edilmiştir. Yapılacak analizin sağlıklı sonuçlar vermesi için durağan olmayan serilerin durağan hale getirilmesi veya modelden çıkarılması gerekmektedir. Bu amaçla serilerin birincil farkları alınarak birim kök testleri tekrar yapılmış ve serilerin birincil farklarında birim kök içermediği görülmüştür. Bu doğrultuda modellerde ilgili serilerin birincil farkları alınarak bu seriler modellere dâhil edilmiştir. Ayrıca modellerde Net işletme sermayesi değişkeninde logaritması alınarak kullanılmasına karar verilmiştir.

Panel veri analizinde farklı yöntemler bulunmaktadır. Bunlar: havuzlanmış en küçük kareler yöntemi, sabit etkiler ve rassal etkiler yöntemleridir. Bu yöntemlerden hangisinin kullanılacağını tespit etmek amacıyla çeşitli istatistiki testler kullanılmaktadır. Çalışmada hangi yöntemin kullanılacağına karar vermek amacıyla $F$ Testi, Breusch- Pagan Langrange Çarpanı ve Hausman testi uygulanmıştır. Bu testlerden elde edilen sonuçlar doğrultusunda hangi yöntemin uygulanacağına karar verilmiştir (Dizgil,2018:262).

F testi sabit etkiler modeli ile havuzlanmış en küçük kareler yöntemi arasında tercih yapmak için kullanılmaktadır. Bu test ile verilerin birim ve zamana göre farklılık gösterip göstermediği tespit edilmektedir. F testine ilişkin sonuçlar tablo:7' de yer almaktadır. Eğer olasılık değeri “ 0,05 ” değerinden küçükse H0 hipotezi reddedilir. Modelin sabit ekiler yöntemine göre tahmin edilmesi gerektiği ifade edilir. 
Tablo:8 F Testi Sonuçları

\begin{tabular}{|l|l|l|l|l|}
\hline F testi hipotezi & & İstatistik değeri & Df & Olasılık değeri \\
\hline $\begin{array}{l}\text { H0: } \beta \mathrm{i}=\beta \text { (birey ve } \\
\text { zaman etkisi yoktur) }\end{array}$ & $\begin{array}{l}\text { Yatay kesit } \mathrm{f} \\
\text { Yatay Chi-square }\end{array}$ & $\begin{array}{l}\text { Model1: } 8.916956 \\
\text { Model1: } 109.422551\end{array}$ & $\begin{array}{l}(15,99) \\
15\end{array}$ & $\begin{array}{l}0.000000^{*} \\
0.000000^{*}\end{array}$ \\
\hline & Yatay kesit f & Model1: 7.423074 & $(15,99)$ & $0.000000^{*}$ \\
& Yatay Chi-square & Model1: 95.785852 & 15 & $0.000000^{*}$ \\
\hline
\end{tabular}

*0.05 anlamlılık düzeyini ifade etmektedir.

Tabloya göre her iki modelde de H0 hipotezi reddedilmiştir. Havuzlanmış model yerine sabit etkiler modelinin kullanımı uygun bulunmuştur. Bu testten sonra havuzlanmış model ile tesadüfi etkiler modelinin karşılaştırmasını yapmak amacıyla Breusch-Pagan testi yapılmıştır. İlgili test sonuçları tablo:8'de yer almaktadır. Testin sıfır hipotezine göre Havuzlanmış Regresyon Modeli uygun olduğu kabul edilirken Alternatif hipotezine göre ise Tesadüfi Etkiler Modelinin uygun olduğu kabul edilmiştir.

Tablo:9 Breusch-Pagan Langrange Multiplier(Çarpanı) Testi

\begin{tabular}{|l|l|l|l|}
\hline & Yatay kesit & Zaman periyodu & Her ikiside \\
\hline Breusch-Pagan & $\begin{array}{l}96.43407 \\
(0.0000)\end{array}$ & $\begin{array}{l}1.972672 \\
(0.1602)\end{array}$ & $\begin{array}{l}96.43407 \\
(0.0000)\end{array}$ \\
\hline Model1 & 81.24354 & 3.437515 & 84.68106 \\
Mreusch-Pagan & $(0.0637)$ & $(0.0000)$ \\
\hline
\end{tabular}

* Elde edilen sonuçlar \%5 anlamlı olup $\mathrm{H}_{0}$ reddedilmiştir.

Test sonuçlarına ilişkin tabloyu incelediğimizde her iki modelde de H0 hipotezinin reddedildiğini görmekteyiz. Test sonucunda alternatif hipotez kabul edilmiştir. Bu aşamadan sonra Hausman testi yapılarak seçilecek modelin sabit etkiler yöntemine göre mi yoksa tesadüfi etkiler yöntemine göre mi analiz edileceğini karar verilmektedir. Sabit ve tesadüfi modeller arasındaki en önemli farklardan biri de bağımsız değişkenlerle birimler arasındaki korelasyon ilişkisinin varlığıdır. Eğer bir korelasyon ilişkisi bulunmuyorsa tesadüfi etkiler modeli tercih edilmelidir. Hausman testi analiz sonuçları ise tablo:9'da yer almaktadır.

\section{Tablo:10 Hausman Testi Analiz Sonuçları}

\begin{tabular}{|l|l|l|}
\hline Hausman Testi Hipotezi & Chi-Sq İstatistik & Olasılık değeri \\
\hline $\begin{array}{l}\text { H0: Tesadüfi Etkiler Modeli Uygundur } \\
\text { Ha: Sabit Etkiler Modeli Uygundur. }\end{array}$ & Model1: 27.427553 & 0.0089 \\
& & 0.0000 \\
\hline
\end{tabular}

* elde edilen sonuçlar $\% 5$ düzeyinde anlamlı olup $\mathrm{H}_{0}$ reddedilmiştir.

Hausman testi sonuçlarını incelediğimizde olasılık değerlerinin her iki modelde de " 0,05 ” değerin küçük olduğunu görmekteyiz. Bu durumda H0 hipotezi reddedilmiştir. Panel veri analizinde sabit etkiler yönteminin kullanılmasına karar verilmiştir.

Otokorelasyon gözlemlenen değerler arasındaki benzerliğin zamansal gecikmenin bir fonksiyonu olarak ifade edilmesidir. Modellerde Otokorelasyon sorunu olup olmadığını tespit etmek amaciyla Durbin Watson test istatistik değerine bakılmıştır. Durbin Watson test istatistik değeri 1.85 ile 2,15 arasında ise Otokorelasyon sorunun olmadığı kabul edilebilmektedir. Modellerimizde Durbin Watson test istatistik değerlerine baktığımızda model1 "de "1.91" model2'de ise"1.90" olarak tespit edilmiştir. Bu durumda modellerimizde Otokorelasyon yoktur diyebiliriz (Dizgil, 2018:264).

Tüm bu testler yapıldıktan sonra panel veri uygulamasına geçilmiştir. İlk olarak modell daha sonra ise model2 analiz edilmiştir. Modellere ilişkin sonuçlar aşağıdaki tablolarda yer almaktadır. 
Tablo:11 Model1'e İlişkin Panel Veri Analizi Sonuçları

\begin{tabular}{|l|l|l|l|l|}
\hline Değişkenler & Katsayılar & Std. Hata & T istatistik & Olasılık \\
\hline OSKFARK & 0.009984 & 0.002850 & 3.502716 & 0.0007 \\
\hline LOGNIS & -0.021220 & 0.006498 & -3.265396 & 0.0015 \\
\hline KVBOFARK & -0.367025 & 0.068176 & -5.383492 & 0.0000 \\
\hline UVBOFARK & -0.410361 & 0.079547 & -5.158726 & 0.0000 \\
\hline OKTA & 0.003689 & 0.001932 & 1.908774 & 0.0592 \\
\hline AOTS & -0.000265 & 0.000126 & -2.106122 & 0.0377 \\
\hline C & 0.415102 & 0.110025 & 3.772800 & 0.0003 \\
\hline R2 & 0.673042 & Düzeltilmiş R2 & 0.580569 & \\
\hline F istatistik & 7.278256 & Olasıllk & 0.000000 & \\
\hline
\end{tabular}

Tablo:12 Model2’ye İlişkin Panel Veri Analizi Sonuçları

\begin{tabular}{|c|c|c|c|c|}
\hline Değişkenler & Katsayılar & Std. Hata & T istatistik & Olasılık \\
\hline OSKFARK & 0.006546 & 0.002782 & 2.353343 & 0.0206 \\
\hline LOGNIS & -0.015572 & 0.006307 & -2.468933 & 0.0152 \\
\hline KVBOFARK & -0.297897 & 0.066347 & -4.489967 & 0.0000 \\
\hline UVBOFARK & -0.311024 & 0.077626 & -4.006680 & 0.0389 \\
\hline AOTS & -0.000257 & 0.000123 & -2.092254 & 0.0038 \\
\hline C & 0.317187 & 0.106955 & 2.965626 & 0.502897 \\
\hline R2 & 0.608580 & Düzeltilmiş R2 & & 0.000000 \\
\hline F istatistik & 5.758527 & Olasılık & & \\
\hline
\end{tabular}

Model 1'e ait panel veri analizi sonuçlarının yer aldığı tablo:11'de bağımlı değişkenimiz ekonomik kârlılık oranıdır. Model2'ye ait panel veri analizi sonuçlarının yer aldığı tablo:12'de ise bağımlı değişkenimiz aktif kârlılık oranıdır. Modellerin açıklama gücünü gösteren R2 değeri model1'de \%67, model2'de ise \%60 tür. Modellerin açıklama gücüde oldukça yüksektir. Düzeltilmiş R2 modele eklenen bağımsız değişkenlerden dolayı ortaya çıkabilecek yalancı şişkinliği önlemek amacıyla hesaplanmıştır. Her iki modelde düzeltilmiş R2 değeri\%50'nin üstündedir. Olasılık değeri modelin bütüncül olarak anlamlılı̆̆ını göstermektedir. Bu değer " 0.05 " değerinden küçükse model bütüncül olarak anlamlıdır. Her iki modelde de olasılık değeri " 0.05 " değerinden küçük olduğu için modeller bütüncül olarak anlamlıdır. Model1'de ekonomik kârlılık oranına etki eden faktörlerin analizi yapılmıştır. Tablodan görüleceği üzere ekonomik kârlılık üzerine etki eden faktörler öz sermaye kârlılığı, net işletme sermayesi, kısa vadeli borç oranı, uzun vadeli borç oranı, alacakların ortalama tahsil süresidir. Ayrıca öz sermaye kârlılığı ile ekonomik kârlılık arasında pozitif yönlü bir ilişki bulunurken net işletme sermayesi, kısa vadeli borç oranı, uzun vadeli borç oranı, alacakların ortalama tahsil süresi ile ekonomik kârlılık arasında negatif yönlü bir ilişki tespit edilmiştir. Model2'de ise aktif kârlılık oranına etki eden faktörlerin analizi yapılmıştır. Burada da kısa vadeli borç oranı, net işletme sermayesi, uzun vadeli borç oranı ve öz sermaye kârlılığı değişkenlerinin aktif kârlılığı üzerinde anlamlı bir etkisi olduğu tespit edilmiştir. Buna ek olarak diğer modelde olduğu gibi öz sermaye kârlılığı ile aktif karlılığı arasında pozitif bir ilişki, kısa 
vadeli borç oranı, net işletme sermayesi ve uzun vadeli borç oranı ile aktif karlılı̆̆ 1 arasında ise negatif bir ilişki bulunmuştur. Ayrıca model1'de öz kaynaklar/ toplam aktif değişkeni ile ekonomik kârlılık arasında model2' de de aktif kârlılığı ile alacakların ortalama tahsil süresi arasında da bir ilişki olduğunu söylenebiliriz. Bağımsız değişkenleri kendi arasında gruplandırdığımızda finansal yapıya ilişkin oranlar; kısa vadeli borç oranı, uzun vadeli borç oranı, öz kaynaklar/ toplam aktif oranıdır. Likidite oranları; net işletme sermayesi oranıdır. Faaliyet etkinliği oranları ise alacakların ortalama tahsil süresidir. Kârlılık değişkenlerinden öz sermaye kârlılığı da bağımsız değişken olarak kullanılmıştır. Bu oranlara ilişkin sonuçları grup bazında değerlendirirsek kârlılığı en çok etkileyen değişkenlerin finansal yapı ve likidite oranları grubunda yer alan değişkenler olduğunu söyleyebiliriz. Bu değişkenlerden öz sermaye karlılık oranı ve öz kaynak oranı dışında kalan diğer değişkenlerin ise karlılık üzerinde negatif yönde etkisi olduğu görülmektedir.

\section{SONUÇ VE ÖNERILER}

Karlılık firmalar için önem arz eden bir konudur. Bu hususta firmaların hedefi uzun dönemde karlılı̆̆ sürekli kılmak kısa dönemde ise yüksek düzeyde kar sağlamaktır. Firmalar karlılık hedefi ile kurulmakta ve yatırımlar bu doğrultuda yapılmaktadır. Yatırımcılar herhangi bir firmaya yatırım kararı verirken iki önemli hususu göz önünde bulundurarak yatırım yapmaktadır. Bunlardan ilki firmanın gerçek değeri ile piyasa değeri arasındaki farktır. İkincisi ise firmanın karlılık durumudur. Ancak karlılık tek başına pek bir şey ifade etmezken karlılığın sürekliliğinin sağlanması firmanın piyasa değerini pozitif yönlü olarak etkileyecektir.

Konunun önemine istinaden yapılan bu çalışmada BİST Gıda ve İçecek Endeksinde hisseleri işlem gören ve verilerine tam olarak ulaşılabilen 16 firmanın kârlılı̆̆ına etki eden içsel faktörlerin tespit edilmesi amaçlanmıştır. Burada bahsi geçen içsel faktörler ise firmanın kontrol edebildiği faktörlerdir. Yapılan bu çalışma literatürde yapılan çalışmalardan farklı olarak endeks bazlı ve güncel veriler kullanılarak yapılmıştır. Gıda ve içecek endeksinin seçilme nedeni endekste yer alan firmaların karlılık ve likiditesinin yüksek olduğunun düşünülmesidir. Bu amaç doğrultusunda firmaların 2009-2017 yıllarına ait yıllık bilanço ve gelir tablosu verileri kullanılmıştır. Öncelikle bu veriler kullanılarak analizde kullanılacak finansal oranlar hesaplanmış daha sonra ise bu oranların kârlılık değişkenleri üzerindeki etkisini tespit etmek amacıyla panel veri analizi yapılmıştır. Bu analizde iki farklı model kullanılmıştır. Bu modellerden ilkin de ekonomik kârlılık oranı ikincisin de ise aktif kârlılık oranı bağımlı değişken olarak kullanılmıştır.

Yapılan analiz sonucunda hem ekonomik kârlılık hem de aktif kârlılık oranını öz sermaye kârlılık oranının pozitif yönde etkilediği tespit edilmiştir. Yani öz sermaye kârlılık oranı artıkça aktif kârlılık oranı ve ekonomik kârlılık oranının artış göstereceğini söyleyebiliriz. Buna ek olarak finansal yapıya ilişkin oranlar, likidite oranları ve faaliyet etkinliği oranları ile aktif kârlılık oranı ve ekonomik kârlılık oranları arasında anlamlı bir ilişki olduğu görülmüştür. Burada kısa vadeli borç oranı, uzun vadeli borç oranı, net işletme sermayesi ve alacakların ortalama tahsil süresi ile aktif kârlılık oranı ve ekonomik kârlılık oranları arasında negatif bir ilişki bulunmuştur. Buna göre işletmelerde kısa vadeli ve uzun vadeli borç oranı artıkça kârlılık azalacaktır. Buna ek olarak işletmelerde net işletme sermayesinin artması ve alacakların ortalama tahsil süresinin uzaması da kârlılığı olumsuz yönde etkileyecektir.

Sonuç olarak sermaye yapısında kısa ve uzun vadeli borç kullanımında en uygun dengeyi sağlamaları, borç kullanımında aşırıya kaçmamaları, dönen varlıklar ile kısa vadeli borçlar arasında dengeyi korumaları ve alacakların tahsil süresini mümkün olduğunca düşük tutmaları halinde firmaların hem ekonomik kârlılıklarının hem de aktif kârlılıklarının olumlu yönde etkileneceğini söyleyebiliriz.

Firma kârlılığına etki eden içsel faktörlerin araştıııldığı bu çalışmada bazı kısıtlar mevcuttur. Çalışmadaki ilk kısıt çalışmadan elde edilen sonuçlar sadece BİST Gıda ve İçecek Endeksinde faaliyet gösteren firmalar açısından yorumlanmalıdır. İkinci kısıt ise veri seti aralığının 2009-2017 yılları arasında olmasıdır.

Konu ile ilgili olarak gelecekte yapılacak çalışmalarda farklı endeksler kullanılarak ve veri seti aralığı genişletilerek farklı çalışmalar yapılabilir. 


\section{KAYNAKÇA}

Aksoy, D. (2011). Türkiye'deki Mevduat Bankalarının Finansal Performanslarının Ölçümü Üzerine Bir Uygulama. İstanbul: Yüksek Lisans Tezi, Marmara Üniversitesi Sosyal Bilimler Enstitüsü.

Aktan, B., \& Bodur, B. (2011). Oranlar Aracılı̆̆ı İle Finansal Durumunuzu Nasıl Çözümlersiniz? "Küçük İşletmeler İçin Bir Rehber". Journal of Yaşar University, 49-67.

Albayrak, A. S., \& Akbulut, R. (2008). Karlılığı Etkileyen Faktörler: İMKB Sanayi ve Hizmet Sektörlerinde İşlem Gören Şirketler Üzerine Bir İnceleme. ZKÜ Sosyal Bilimler Dergisi,, 55-83.

Almajali, A., \& Sameer, A.A. (2012). FactorsAffectingthe Financial Performance of JordanianInsurance CompaniesListed at Amman Stock Exchange. Journal of Management Research, 266-289.

Aydın, G. (2009). Tüketici Temelli Marka Değerinin Firmaların Finansal Performansı Üzerine Etkisi: Türkiye'de Bir Çalışma. İstanbul: Doktora Tezi,İstanbul Teknik Üniversitesi Sosyal Bilimler Enstitüsü.

Chen, L. (2012). The Effect of Ownership Structure on Firm Performance: Evidence from Non-financial Listed Companies in Scandinavia. Msc in Finance \& International BusinessAarhus School of Business. Aarhus University.

Coşkun, N., \& Topaloğlu, E. E. (2016). Makroekonomik Faktörlerin Finansal Performansa Etkisi: Borsa İstanbul Firmaları Üzerine Ekonometrik Bir Uygulama. ICOMEP 2016 International Congress of Management Economy and Policy Proceedings Book, 1-18.

Dizgil, E. (2018). Bist Ticaret Endeksinde Yer Alan Şirketlerin Springate Finansal Başarısızlık Modeli İle İncelenmesi. Bilecik Şeyh Edebali Üniversitesi Sosyal Bilimler Enstitüsü Dergisi, 248-267.

Doğan, M., \& Topal , Y. (2016). Karlılığı Belirleyen Finansal Faktörler: BIST’te İşlem Gören İmalat Sanayi Firmaları Üzerine Bir Araştırma. Optimum Ekonomi ve Yönetim Bilimleri Dergisi, 53-64.

Haniffa, R., \& Hudaib, M. (2006). Corporate Governance Structure and Performance of Malaysian Listed Companies. Journal of Business Finance \& Accounting, 1034-1062.

Karadeniz, E. T. (2011). İstanbul Menkul Kıymetler Borsası'nda İşlem Gören Turizm İşletmelerinin Aktif Karlı1ı̆̆ını Etkileyen Değişkenlerin Analizi. Anatolia/ Turizm Araştırmaları Dergisi, 65.

Kocaman, M., Altemur, N., Aldemir, S., \& Karaca, S. S. (2016). Ekonomik Karlılığı Etkileyen Faktörler: İSO 500 Sanayi İşletmeleri Uygulaması. Mustafa Kemal Üniversitesi Sosyal Bilimler Enstitüsü Dergisi, 320-332.

Korkmaz, Ö., \& Karaca, S. S. (2014). Üretim İşletmelerinde Firma Karlılı̆ı̆ının Finansal Belirleyicileri ve BİST İmalat Sanayi Uygulaması. Ege Akademik Bakış, 21-29.

Ocak 2019 tarihinde Kamuyu Aydınlatma Platformu: https://www.kap.org.tr/tr/ adresinden alındı

Tatoğlu, F. Y. (2012). Panel veri ekonometrisi: Stata uygulamalı. Beta Basım Yayın.

Ujunwa, A. (2012). Board Characteristics and the Financial Performance of Nigerian Quoted Firms. Corporate Governance, 1-30. 